\title{
RISK MANAGEMENT OF OYSTER MUSHROOM AGRIBUSINESS IN JEMBER DISTRICT
}

\author{
Andriansyah Setiawan Saputra, Evita Soliha Hani, Luh Putu Suciati \\ Agribusiness Study Program, Faculty Of Agriculture, University of Jember \\ andreanssyah10@gmail.com
}

\begin{abstract}
The purpose of this study was to determine the risk management of oyster mushroom agribusiness in Jember District. Oyster mushroom farming as an alternative to post harvest and can be used for meat and fish substitution foods. In fact there is a factors that are difficult to predict, easy to change and cannot be controlled. Constraints in agricultural excellence such as environmental risk, production risk, supply risk and demand risk. Implementation management needs to be done to minimize the aspects to be disputed. one of the risk management methods is the FMEA method (Failure Mode and Effect Analysis), this method is useful to identify and allow as much as possible. The research method used in literature studies. Study results show the highest risk are contamination, pest disorders, inoculation, media sterilization dan sifting of raw materials
\end{abstract}

Keywords : Oyster Mushroom, Risk Management

\section{Introduction}

Agricultural development with sustainability and independence must continue to be carried out in anticipation of world food scarcity which is increasingly apparent. It is estimated that the world population will increase from 9 billion in 2050 which was previously known to be only around 7 billion in 2011. Efforts in realizing agricultural development cannot be separated from several problems such as decreasing the quality and quantity of agricultural land resources, limited availability of agricultural supporting infrastructure, weaknesses in technology transfer systems, access to capital services and the length of the agricultural trade management chain (Yusuf, 2013). Food security in Indonesia is stated in Law No. 7 of 1996 concerning food which states that food security is a condition of fulfilling household food (RT), which is reflected in the availability of adequate food, both in quantity and quality, safe and evenly distributed and affordable. Business in agriculture in Indonesia is a production process that follows the law of energy flow, which means that the overall yield is in the form of plant biomass. During this time after the main results are taken (post-harvest) usually most of the biomass that has been produced must be disposed of in the form of waste. There are several alternatives that can be done to overcome this problem, one of which is as a raw material for oyster mushrooms. Oyster mushrooms as a solution to waste utilization and can be used as food substitute for meat or fish. High nutrient content compared to other mushrooms can provoke people to consume processed oyster mushrooms so that they have good potential to be developed (Purwoko, 2006).

The prospect of oyster mushroom farming in Jember Regency is quite good because of the natural conditions and the availability of cheap and abundant raw materials. Fresh oyster mushrooms in Jember Regency at the farm level have a high price ranging from Rp.10,000 / kg to Rp.12,000 / kg. Oyster mushrooms are 
agricultural crops that are closely related to natural factors in influencing production yields. Natural factors are factors that are difficult to predict, easy to change and cannot be controlled. Risk management is a step that must be done by agricultural actors to find out the risks in farming that are considered risky. The application of risk management is done to minimize the risks that will be faced in agricultural businesses (Yulia, 2013).

Objective

1. to find out the risks that occur in oyster mushroom farming

2. to find out the most influential risk and risk level

3. to find out risk management in oyster mushroom farming in Jember Regency

\section{Research Methodology}

Determination of the research area is Purposive Method. Precisely Jember Regency with consideration of UD. Mitra Jamur Jember. has great business potential and capacity in terms of providers of oyster mushroom production facilities compared to other oyster mushroom businesses in the Jember area. UD. Mitra Jamur Jember has partnered with oyster mushroom farmers. Sampling for partner farmers is 40 people, which means using total sampling by conducting interviews directly using questionnaires. Data analysis using FMEA (Failure Mode and effect analiysis) starts with measuring the value of severity, occurance and detection. FMEA is a procedure that is useful for identifying and preventing as many modes of failure as possible in a company (Almannai et al, 2008)). FMEA analysis includes

1) Severity(Severity), an assessment of the seriousness of the effects of this form of potential failure.

2) Occurrence(occurance), is often what causes the failure of a project happen.

3) Detection (Detection), is an assessment of the possibility that the tool can detect potential causes of a form of failure.

4) Risk priority number(Risk Priority Number (RPN)) is a risk priority number obtained by multiplying severity, occurance and Detection.

5) An act which is recommended(recommended action), after the shape of the failure arranged according to rank RPNnya, immediate action from improvements to the shape of the failure to score highest RPN

\section{Results}

farming oyster mushroom(Pleurotusostreatus) is the process of farming in which the production process takes less than a month with a future cultivation for 4 - 6 months. Oyster mushroom farming requires skills and perseverance in the process (Lutuharheri, 2003). It is known that there are several risks in oyster mushroom farming in Jember Regency that have an impact on the quality and quantity of oyster mushroom production obtained, namely weather changes, pest disturbance, contamination, sifting of raw materials, stirring of raw materials, making media, 
sterilization, cooling media, inoculation, incubation, quality and quantity of raw materials, late delivery performance to farmers, high order adjustment of raw material costs by unilateral cancellations by consumers, presence of competitors, late delivery and fluctuating demand. In analyzing the level of risk that occurs, farmers as the main actors and as the assessment team in determining the highest failure based on each score. The FMEA method is used to identify, find potential failures and prevent as many modes of failure as possible in a farm. Based on the risks listed and the known value of each RPN, the risk level can be identified and then proposed improvements. Obtained results analysis of the risk level of oyster mushroom farming as follows:

Table 1. Severity, Occurance, Detection, RPN and Risk Levels in Oyster Mushroom Farming in Jember Regency

\begin{tabular}{|c|l|c|c|c|c|c|}
\hline No & \multicolumn{1}{|c|}{ Variable } & Severity & Occurance & Detection & RPN & Risk Level \\
\hline 1 & Weather Change & 5.3 & 5.2 & 3,1 & 86.1 & high \\
\hline 2 & Pest Disorders & 6.0 & 6.6 & 3.8 & 150.8 & high \\
\hline 3 & Contamination & 8.2 & 7.6 & 5.5 & 336.4 & very critical \\
\hline 4 & Raw Materials & 6.0 & 5.2 & 4,0 & 123.3 & height \\
\hline 5 & $\begin{array}{l}\text { Stirring Raw } \\
\text { Materials }\end{array}$ & 4.3 & 4.6 & 3.2 & 63.4 & high \\
\hline 6 & Media Making & 2.3 & 3.8 & 3.2 & 27.5 & low \\
\hline 7 & $\begin{array}{l}\text { Sterilization of } \\
\text { media baglog }\end{array}$ & 6.2 & 5.2 & 3,9 & 124.7 & high \\
\hline 8 & Cooling & 2.2 & 3.7 & 2.7 & 21.1 & low \\
\hline 9 & Inoculation & 7.0 & 4.8 & 3.9 & 128.5 & high \\
\hline 10 & Incubation & 2.3 & 4.6 & 2.2 & 23.4 & low \\
\hline 11 & $\begin{array}{l}\text { Quality and } \\
\text { Quantity of Raw } \\
\text { Materials }\end{array}$ & 2.5 & 4.5 & 2.8 & 31.2 & medium \\
\hline 12 & $\begin{array}{l}\text { Performance Late } \\
\text { delivery }\end{array}$ & 3.3 & 4.0 & 2.8 & 36.3 & medium \\
\hline 13 & $\begin{array}{l}\text { High Raw } \\
\text { Material Costs }\end{array}$ & 4.7 & 3.2 & 3.6 & 54.0 & Medium \\
\hline 14 & $\begin{array}{l}\text { Booking } \\
\text { Adjustments }\end{array}$ & 4.3 & 3.6 & 2.2 & 33.9 & Medium \\
\hline 15 & $\begin{array}{l}\text { Unilateral } \\
\text { Cancellation }\end{array}$ & 4.5 & 3.3 & 2.7 & 38.8 & Medium \\
\hline 16 & $\begin{array}{l}\text { Existing } \\
\text { Competitors }\end{array}$ & 3.4 & 5.8 & 2.9 & 56,8 & medium \\
\hline 17 & Delay in Delivery & 4.0 & 3.3 & 3.8 & 3.6 & Medium \\
\hline 18 & $\begin{array}{l}\text { Fluctuating } \\
\text { Demand }\end{array}$ & 3.4 & 36.2 & Medium \\
\hline
\end{tabular}

Source: Data Processed in 2018 
Table 2 Potential Failure Modes in Oyster Mushroom Farming in Jember Regency

\begin{tabular}{|c|l|l|}
\hline No & \multicolumn{1}{|c|}{ Description } & \multicolumn{1}{c|}{ Potential Failure Modes } \\
\hline 1 & Changes in weather & Erratic weather, Change too fast \\
\hline 2 & Pest Disorders & Sciarid, caterpillar, and mice \\
\hline 3 & Contamination of & Trichoderma and Coprinus sp \\
\hline 4 & Sifting of Raw Materials & $\begin{array}{l}\text { Sorting fine powder with coarse, oily wood odor } \\
\text { from sawmills }\end{array}$ \\
\hline 5 & Stirring Raw Materials & $\begin{array}{l}\text { amount of water is sometimes excessive or } \\
\text { lacking, raw materials expired }\end{array}$ \\
\hline 6 & Baglog media sterilization & $\begin{array}{l}\text { Leaks in drums and inner drums } \\
\text { The sterilization process is too long, sometimes too } \\
\text { fast }\end{array}$ \\
\hline 7 & Inoculation & $\begin{array}{l}\text { place is not clean, the equipment used is less } \\
\text { sterile, }\end{array}$ \\
\hline 8 & $\begin{array}{l}\text { The Quality and Quantity of } \\
\text { Raw Materials }\end{array}$ & $\begin{array}{l}\text { capacity of wood powder sent is less. Dry and } \\
\text { hard raw material (Katul) }\end{array}$ \\
\hline 9 & Performance Late & delivery Supplier time delay, shipping constraints \\
\hline 10 & $\begin{array}{l}\text { High high cost of Raw } \\
\text { Material }\end{array}$ & material step \\
\hline 11 & Order adjustment & $\begin{array}{l}\text { Not according to order usually suppliers send too } \\
\text { much hard wood }\end{array}$ \\
\hline 12 & Unilateral cancellation & No clarity in the cancellation \\
\hline 13 & Competitors & $\begin{array}{l}\text { Competing around the village or sub-district } \\
\text { Cheaper price }\end{array}$ \\
\hline 14 & Delay in the delivery & $\begin{array}{l}\text { oyster mushrooms withering and yellow (quality } \\
\text { degradation) }\end{array}$ \\
\hline 15 & Fluctuating Daily & Demand for ups and downs \\
\hline
\end{tabular}

Source: Data processed in 2018

Table 3 RPN rankings and proposed improvements for each - failure On Oyster Mushroom Farming in Jember Regency

\begin{tabular}{|c|l|c|cl|}
\hline Rank & \multicolumn{1}{|c|}{ Description } & RPN & \multicolumn{1}{|c|}{ Proposed Improvement } \\
\hline 1 & Contamination & 336.4 & $\begin{array}{l}1 . \\
\text { 2leanliness of raw materials and } \\
\text { equipment. } \\
\text { cleanliness of the garden Periodic }\end{array}$ \\
\hline 2 & Pest Disorders & 150,8 & $\begin{array}{l}1 . \\
2 .\end{array}$ & $\begin{array}{l}\text { Use of natural insecticides. } \\
\text { Use of trap lights and fly netting }\end{array}$ \\
\hline 3 & Inoculation & 128.5 & 1. & $\begin{array}{l}\text { Sterilization of equipment using } \\
\text { methanol Sterilization of } \\
\text { room cleanliness }\end{array}$ \\
\hline 4 & $\begin{array}{l}\text { Sterilization of media } \\
\text { baglog }\end{array}$ & 124.7 & $\begin{array}{l}1 . \\
2 .\end{array}$ & $\begin{array}{l}\text { Replacement of drum water every time } \\
\text { a good inner cover }\end{array}$ \\
\hline 5 & Sifting of raw materials & 123.3 & $\begin{array}{l}1 . \\
2 .\end{array}$ & $\begin{array}{l}\text { Using a small and undamaged net } \\
\text { Selecting wood powder to be sifted }\end{array}$ \\
\hline
\end{tabular}




\begin{tabular}{|c|c|c|c|}
\hline 6 & Changes in weather & 86.1 & $\begin{array}{l}\text { 1. Watering kumbung and ground level - } \\
\text { Making soil with fertilizer kendang }\end{array}$ \\
\hline 7 & Stirring raw material & 63.4 & $\begin{array}{l}\text { 1. Measuring water that fits } \\
\text { 2. the raw material according to the rules } \\
(100 \mathrm{~kg} \text { of wood powder, } 15 \mathrm{~kg} \text { rice } \\
\text { pulley, } 3 \mathrm{~kg} \text { corn curry, one cup of cast })\end{array}$ \\
\hline 8 & Presence of competitors & 56.8 & $\begin{array}{l}\text { 1. Increasing consumer partners } \\
\text { 2. Strengthening relationships with } \\
\text { consumers }\end{array}$ \\
\hline 9 & High raw material costs & 54.0 & $\begin{array}{l}\text { 1. Looking for alternative raw materials } \\
\text { 2. Reducing raw materials by adding other } \\
\text { raw materials }\end{array}$ \\
\hline 10 & $\begin{array}{l}\text { Delay delivery to } \\
\text { consumers }\end{array}$ & 50,9 & $\begin{array}{l}\text { 1. Make a delivery schedule. } \\
\text { 2. Consistency of delivery time }\end{array}$ \\
\hline 11 & Fluctuating demand & 46.2 & $\begin{array}{l}\text { 1. Looking for other customers through } \\
\text { social media groups } \\
\text { 2. Perform post-harvest processing if } \\
\text { demand is small but production is much } \\
\text { 3. sought out partner farmers if demand is } \\
\text { large but production is low }\end{array}$ \\
\hline 12 & Unilateral cancellation & 38.8 & $\begin{array}{l}\text { 1. Looking for other customerscustomer } \\
\text { 2. Strengtheningrelations }\end{array}$ \\
\hline 13 & Delivery performance late & 36.3 & $\begin{array}{l}\text { 1. Order raw materials far in advance } \\
\text { 2. Looking for a competitive supplier and } \\
\text { guarantee delivery time }\end{array}$ \\
\hline 14 & Order adjustment & 33.9 & 1. Sorting raw materials and sorting them \\
\hline 15 & $\begin{array}{l}\text { Quality and quantity of } \\
\text { raw materials }\end{array}$ & 31.2 & $\begin{array}{l}\text { 1. Sorting raw materials. } \\
\text { 2. Finding competitive suppliers }\end{array}$ \\
\hline
\end{tabular}

Source: Data Processed in 2018

\section{Conclusions and Recommendations}

It is known that there are 18 risks that occur in oyster mushroom farming. 3 risks fall into the low category, while 8 is included in the medium risk. Risks with a high level of 6 kinds of risks and very critical risks are only 1 risk. The potential failure mode on oyster mushroom farming consists of 15 types obtained from several process failures. The risk of failure in FMEA results is used as a priority in proposed improvements. The biggest failure on RPN that has a value above 100 is in the form of contamination, pest disruption, inoculation, baglog media sterilization and sifting of raw materials.

Proposed improvements are by cleaning raw materials, equipment, rooms and garden. The use of natural insecticides and the use of trap lights and fly netting for risks to pest disorders. Substitution of drum water in each sterilization process using a 
good inner antler for the risk of baglog media sterilization. To minimize the risk of sifting raw materials for farmers, it is necessary to use a smaller net.

\section{List of References}

Almannai,, Greenough, R. and Kay, J. (2008). A decision support tool based on QFD and FMEA for the selection of manufacturing automation technologies. Vol 24: 501-507

Lutuharheri, 2003. Production Cost Analysis of White Oyster Mushroom Cultivation in Bogor Region. Bogor. Bogor Agricultural University

Purwoko and Arkeman. 2006. Feasibility of Oyster Mushroom Krupuk Industry in Bogor Regency. Journal of Agricultural Industrial Technology Vol. 13 (3): 83-91.

Yulia Alviany. 2013. Risk Management Analysis of Mango Farming in Indramayu District, West Java. Essay. Bogor: Bogor Agricultural Institute

Yusuf, Nurdin 2013. Problems Concerning Agricultural Development in Indonesia. https://muhamadnurdinyusuf.wordpress.com/2013/01/23/5-masalah-yangmembelit-pembangunan-pertanian-di-indonesia (Accessed on March 14, 2018) 